\title{
UPAYA MENINGKATKAN HASIL BELAJAR MAHASISWA MELALUI MODEL PEMBELAJARAN QUESTIONING TYPE OPEN ENDED PROBLEMS
}

\author{
Ika Wirahmad \\ Program Studi Pendidikan Matematika \\ Sekolah Tinggi Keguruan dan Ilmu Pendidikan (STKIP) Bima \\ Wirahmad.71@gmail.com
}

\begin{abstract}
ABSTRAK
Model pembelajaran yang diterapkan oleh Dosen untuk menigkatkan hasil belajar Mahasiswa harus sesuai dengan tujuan yang ingin dicapai. Oleh karena itu peneliti mencoba menerapkan Model pembelajaran Questioning Open Ended Problems pada Mahasiswa STKIP Bima pada materi Instruksi Basic Elementer tahun Akademik 2017/2018, Tujuan penelitian adalah untuk meningkatkan hasil belajar melalui penerapan Model pembelajaran Questioning Open Ended Problems. Jenis penelitian yang digunakan adalah Penelitian Tindakan Kelas (PTK) dengan Model Kemmis \& mc.Tagart. Subyek dari penelitian ini adalah Mahasiswa kelas A Semester II Program studi pendidikan Matematika STKIP Bima Tahun Akademik 2017-2018 yang terdiri dari 26 Mahasiswa.. Instrumen penelitian yang digunakan adalah Tes dan observasi. Indikator keberhasilannya adalah aktivistas Dosen dan Mahasiswa yang minimal berkategori Baik dan Aktif, ketuntasan klasikal $\geq 85 \%$ Mahasiswa mandapat nilai $\geq 65$ pada saat evaluasi. Dari hasil penelitian menunjukan adanya peningkatan dari sebelum dan sesudah menerapkan Model pembelajaran Questioning Open Ended Problems. Peningkatan persiklus didapat dari skor rata - rata Mahasiswa persiklus 63,88 dengan ketuntasan 65,36\% meningkat menjadi 71,81 dengan ketuntasan $88,46 \%$. Hasil ini telah memenuhi kriteria ketuntasan sesuai dengan indikator kerja. sehingga Model pembelajaran Questioning Open Ended Problems dapat meningkatkan hasil belajar Mahasiswa kelas A Semester II Program studi pendidikan Matematika STKIP Bima Tahun Akademik 2017-2018 materi Instruksi Basic Elementer dengan karakteristik pada mata kuliah Bahasa Pemrograman..
\end{abstract}

Kata kunci: Questioning Open Ended Problems, Hasil Belajar. 


\begin{abstract}
The learning model applied by the lecturer to improve student learning outcomes must be in accordance with the objectives to be achieved. Therefore researchers tried to apply the Questioning Open Ended Problems learning model to STKIP Bima students in Basic Elementary Academic Year 2017/2018 Instruction material. The aim of the study was to improve learning outcomes through the application of Questioning Learning Models to Open Ended Problems. The type of research used is Classroom Action Research (CAR) with Model Kemmis \& mc.Tagart. The subjects of this study were Class A Semester II Students of the 2017-2018 Academic Year STKIP Bima Mathematics Education Study Program consisting of 26 students. The research instruments used were tests and observations. The indicator of success is the activities of Lecturers and Students who are at least categorized as Good and Active, classical completeness $\geq 85 \%$ of Students have a value of $\geq 65$ at the time of evaluation. From the results of the study showed an increase from before and after applying the Questioning Learning Model Open Ended Problems. The increase in persiklus obtained from the average score of students in the cycle of 63.88 with completeness $65.36 \%$ increased to 71.81 with completeness $88.46 \%$. These results have met the completeness criteria in accordance with work indicators. so that the Learning Model Questioning Open Ended Problems can improve the learning outcomes of Class A Semester II Students of STKIP Bima Mathematics Education Program 2017-2018 Basic Elementary Instructions with the characteristics of the Programming Language course ..
\end{abstract}

Keywords: Questioning Open Ended Problems, Learning Outcomes. 


\section{PENDAHULUAN}

Pendidikan pada hakikatnya adalah proses pendewasaan Peserta Didik menuju sikap yang bertanggung jawab baik dalam pola pikir maupun tingkah laku. Dengan demikian, dalam meningkatkan mutu lembaga pendidikan tersebut perlu dilakukan pembenahan secara terus menerus, yakni diantaranya dengan proses pembelajaran yang efektif serta pembelajaran yang berkualitas.

Perkembangan ilmu pengetahuan dan teknologi yang begitu cepat dewasa ini secara langsung mempengaruhi kehidupan manusia terutama dalam bidang teknologi komunikasi dan informasi. Teknologi informasi saat ini merupakan tantangan bagi sendi-sendi kehidupan bermasyarakat, berbangsa, dan bernegara. Kenyataan ini memicu upaya pengembangan sumber daya manusia yang berkualitas melalui proses pendidikan. Seiring dengan upaya peningkatan kualitas sumber daya manusia di negara kita, maka kualitas proses pendidikan juga harus ditingkatkan. Upaya peningkatan kualitas pendidikan pada semua jenjang telah dan akan dilaksanakan oleh pemerintah melalui Departemen Pendidikan Nasional, seperti: pengadaan sarana pembelajaran, pembaharuan kurikulum, serta peningkatan kualifikasi pendidikan bagi tenaga pendidik atau Dosen.

Sebagai partisipasi pendidikan, Dosen memiliki peranan dan tanggung jawab yang sangat besar dalam pencapaian tujuan pembelajaran. Namun demikian, disadari dan dimaklumi barsama bahwa pencapaian tujuan pembelajaran harus didukung oleh berbagai faktor, salah satu diantaranya adalah kemampuan merancang dan menggunakan model/metode pembelajaran yang sesuai dengan materi yang akan di pelajari oleh Peserta Didik.

Sesuai dengan pernyataan tersebut, apabila ingin mengerjakan sesuatu kepada peserta didik dengan baik dan berhasil, pertama-tama yang harus diperhatikan adalah metode atau cara pendekatan yang dilakukan, sehingga sasaran yang diharapkan dapat tercapai atau terlaksana dengan baik, karena metode atau cara pendekatan yang dalam fungsinya merupakan alat untuk mencapai tujuan (Lisnawati, 1993).

Model pembelajaran yang diterapkan oleh seorang pengajar untuk meningkatkan hasil belajar peserta didiknya harus sesuai dengan tujuan yang ingin dicapai, materi perkuliahan, karakteristik peserta didik, karakteristik mata kuliah dan dapat melibatkan kreativitas mental 
dan motorik peserta didik. Rendahnya Hasil belajar Peserta Didik ini, tidak lepas dari pengaruh Pengajar, karena Pengajar adalah orang yang memandu jalannya proses belajar mengajar. Pengajar bertugas untuk mengantarkan peserta didik menguasai materi serta keterampilan-keterampilan yang dikemas dalam kurikulum. Seorang Pengajar harus dapat memfasilitasikan dirinya dengan segenap pengalaman, keterampilan, dan pengetahuan tentang Pembelajaran. Tujuan pembelajaran akan tercapai secara baik jika seorang Pengajar mampu mengembangkan kreatifitas pembelajaran. Dalam mengajarkan suatu pokok bahasan tertentu, Pengajar harus mampu memilih model pembelajaran yang sesuai dengan karakteristik pokok bahasan yang akan diajarkan. Ketepatan model pembelajaran yang digunakan sangat menentukan efektifitas dan efisiensi proses belajar Peserta Didik. Disamping kemampuan memilih model pembelajaran, Pengajar juga harus mampu memilih strategi yang tepat dan mampu memanfaatkan alat bantu pembelajaran serta sumber belajar untuk memperoleh hasil yang optimal bagi setiap Peserta Didik. Selain Pengajar dan buku, Peserta Didik juga bisa menjadi sumber belajar bagi Peserta Didik lainnya (Djamarah, 1994:24-27).

Berdasarkan pengalaman kami sebagai pengajar, lebih khusus mata kuliah yang peneliti ajarkan yaitu Bahasa Pemrograman Komputer, dimana pengajar dengan peserta didik sangat perlu adanya komunikasi yang membangun, sehingga proses pembelajaran menjadi hidup dan bersemangat baik bagi peserta didik maupun pengajarnya.. Pengajar perlu melibatkan Peserta Didik secara aktif dalam proses pembelajaran, membuat Peserta Didik bertanya, mempelajari sendiri, mendiskusikan dan menemukan sendiri konsep-konsep yang terkandung di dalam materi perkuliahan. Permasalahan di atas akhirnya berdampak pada rendahnya hasil belajar Peserta Didik, jika tidak direspon dengan cepat, hal tersebut dapat dilihat dari presentase ketuntasan belajar Peserta Didik pada tabel presentase ketuntasan belajar Peserta Didik berikut.

Tabel 1: Presentase ketuntasan belajar Peserta Didik Semester I Program Studi Pendidikan Matematika STKIP Bima tahun Akademik 2017-2018.

\begin{tabular}{|c|c|c|c|c|}
\hline No & Kelas & $\begin{array}{l}\text { Banyak Peserta Didik yang } \\
\text { Memperoleh nilai } \geq 65\end{array}$ & $\begin{array}{l}\text { Banyak Peserta Didik yang } \\
\text { Memperoleh nilai } \leq 65\end{array}$ & $\begin{array}{l}\text { Presentase } \\
\text { Ketuntasan }\end{array}$ \\
\hline $\mathbf{1}$ & $\mathbf{A}$ & $\mathbf{1 7}$ & $\mathbf{9}$ & $\mathbf{6 5 , 3 6 \%}$ \\
\hline
\end{tabular}




\begin{tabular}{|l|l|l|l|l|}
\hline 2 & B & 24 & 4 & $85,7 \%$ \\
\hline
\end{tabular}

Berdasarkan data diatas dapat dilihat bahwa presentase ketuntasan belajar Peserta Didik Kelas A pada semester I masih dibawah ketuntasan, maka peneliti menggunakan Peserta Didik kelas A Semester II Program studi pendidikan matematika STKIP Bima sebagai subjek dalam penelitian. Menurut pengalaman Pengajar Mata Kuliah Dasar-dasar Komputer Program studi pendidikan matematika STKIP Bima, disebabkan karena kurangnya interaksi antara Peserta Didik dan Pengajar, Peserta Didik dengan Peserta Didik, dan kurangnya minat Peserta Didik terhadap mata Kuliah Mata Kuliah Dasar-dasar Komputer yang konsep-konsep materinya masih banyak yang kurang mengerti. Sehingga Peserta Didik kurang teliti dalam memecahkan masalah sendiri.

Dari permasalahan yang telah diuraikan diatas, jelas dibutuhkan suatu model pembelajaran yang dapat mengajak Peserta Didik berperan aktif dalam proses belajar mengajar. Untuk menerapkan model pembelajaran yang tepat maka seorang Pengajar harus menguasai trik-trik pembelajaran dan menguasai berbagai model pembelajaran. Suprijono (2009) mengemukakan bahwa model pembelajaran adalah pola yang digunakan sebagai pedoman dalam merencanakan pembelajaran di kelas maupun tutorial. Dengan menggunakan model pembelajaran yang tepat akan dapat meningkatkan keaktifan Peserta Didik dalam menguasai dan memahami materi pembelajaran dan dapat pula meningkatkan Hasil belajar Peserta Didik, sehingga tujuan pembelajaran yang ditingkatkan dapat tercapai. Pembelajaran akan lebih bermakna jika Peserta Didik ikut aktif dalam proses belajar mengajar, aktif dalam mencari dan mengelola informasi, dan aktif dalam bertanya dan menemukan gagasan untuk menentukan suatu konsep, sehingga Peserta Didik dapat menyimpulkan sendiri tentang materi pembelajaran. Pengajar hanya sebagai fasilitator, sehingga Peserta Didik tidak sukar mencari informasi melalui Pengajar saja. Untuk mengaplikasikan hal tersebut, Pengajar dituntut untuk lebih aktif dalam menentukan model pembelajaran yang akan digunakan, sehinga dapat melibatkan Peserta Didik dalam menentukan konsep-konsep dalam memecahkan masalah.

Salah satu cara untuk mengatasi masalah diatas adalah dengan menggunakan model pembelajaran Questioning Type Open Ended Problems. Model pembelajaran Questioning 
Type Open Ended Problems merupakan salah satu tipe pembelajaran yang dapat mengaktifkan Peserta Didik agar dapat mengajukan pertanyaan dan mengemukakan gagasannya, sehingga diharapkan dapat meningkatkan aktivitas dan Hasil belajar Peserta Didik. Pada model Questioning Type Open Ended Problems ini, Peserta Didik diharapkan dapat termotivasi dalam perkuliahan dan potensi Peserta Didik dapat dimaksimalkan.

Nilai rata-rata yang diperoleh Peserta Didik kelas A Semester I Program Studi pendidikan Matematika STKIP Bima pada pembelajaran Mata kuliah Dasar-dasar Komputer yang di dalamnya terdapat materi Sistim Bilangan memiliki nilai dibawah KKM. Sehingga peneliti memilih materi Bahasa Pemrograman pada semester II ini, dalam proses pembelajaran menggunakan model pembelajaran Questioning Type Open Ended Problems. Dengan memperhatikan hal tersebut diatas, peneliti akan mengadakan penelitian dengan judul "UPAYA MENINGKATKAN HASIL BELAJAR MAHASISWA MELALUI MODEL PEMBELAJARAN QUESTIONING TYPE OPEN ENDED".

\section{METODE PENELITIAN}

Jenis penelitian yang digunakan adalah Penelitian Tindakan Kelas (PTK). Penelitian Tindakan Kelas adalah suatu bentuk penelitian yang bersifat refleksif dengan melakukan tindakan-tindakan tertentu agar dapat memperbaiki dan meningkatkan praktek-praktek pembelajaran di kelas secara profesional (Muslich, 2009:9).

Penelitian tindakan kelas adalah bagaimana sekelompok Pengajar dapat mengorganisasikan kondisi praktek pembelajaran mereka, dan belajar dari pengalaman mereka sendiri. Mereka dapat mencobakan sesuatu gagasan perbaikan dalam praktek pembelajaran mereka dan melihat pengaruh nyata dari upaya itu.(Dewei,1933 dalam Mathison,1994: 23). Penelitian ini dilaksanakan di Program studi pendidikan Matematika STKIP Bima Kelas A Semester II tahun akademik 2017-2018, Penerapan medel pembelajaran questioning type open ended problems pada materi pokok Perintah (Statement) yang bertujuan untuk meningkatkan Hasil Belajar Peserta Didik kelas A Ssemester II Program studi pendidikan Matematika STKIP Bima Tahun Akademik 2017-2018. Penelitian ini direncanakan menggunakan beberapa siklus dengan menggunakan Model PTK Kemmis dan Mc. Taggart, yang tiap siklusnya terdapat 4 tahap yaitu perencanaan, pelaksanaan, observasi/evaluasi, dan refleksi, Siklus Spiral. 
Adapun instrumen yang diberikan pada pembelajaran ini yaitu Test Hasil Belajar Peserta Didik dimana Hasil belajar Peserta Didik diperoleh dengan menggunakan tes hasil belajar Peserta Didik melalui pemberian tes evaluasi menggunakan soal essay, ini dibuat guna untuk mengetahui sampai sejauh mana pemahaman Peserta Didik dalam menguasai materi yang telah dipelajari, Sedangkan Pedoman observasi aktivitas belajar Peserta Didik digunakan untuk memperoleh gambaran langsung tentang aktivitas belajar Peserta Didik dalam pembelajaran di kelas selama proses pembelajaran Bahasa Pemrograman menggunakan model pembelajaran questioning type open ended problems. Pedoman observasi ini meliputi observasi aktivitas belajar Peserta Didik yaitu menulis, membaca, menyimak sekaligus merespon materi yang di sampaikan.

Untuk mengetahui aktivitas belajar Peserta Didik dan aktivitas Pengajar dalam pengelolaan pembelajaran dikumpulkan dengan menggunakan pengisisan lembar observasi. Pengamatan dalam melakukan pengisian lembar observasi memberikan tanda cek $(\sqrt{ })$ pada kolom yang telah disediakan sesuai dengan indikator perilaku yang nampak.

Hasil belajar Peserta Didik diperoleh dengan cara memberikan tes evaluasi pada Peserta Didik setiap akhir siklus untuk menentukan ketuntasan individual dan ketuntasan klasikal terhadap indikator yang telah ditetapkan. Ketuntasan individual menurut standar ketuntasan belajar berdasarkan Kurikulum Tingkat Satuan Pendidikan berisi tentang keriteria dan mekanisme penetapan ketuntasan minimal mata pembelajaran Bahasa Pemrograman yang ditetapkan Pembina Mata Kuliah, setiap Peserta Didik adalah $\geq 65$. Sedangkan suatu kelas dikatakan tuntas belajarnya jika dikelas tersebut terdapat $\geq 85 \%$.

Peserta Didik yang telah mencapai ketuntasan individual. Setiap indikator perilaku Peserta Didik pada penelitian ini dapat dinilai dengan cara pemberian skor, Untuk mengetahui aktivitas Peserta Didik dalam pembelajaran, maka data hasil observasi yang berupa skor total dari setiap indikator yang diamati dianalisis secara desktiptif mengunakan norma absolut skala lima, Mencari Skor Maksimal Ideal (SMI). Dalam hal ini kaitannya dengan aktivitas belajar Peserta Didik.. Untuk 6 indikator dengan skor maksimal 20 , Membuat pedoman konversi yang digunakan dalam mengubah skor mentah menjadi skor standar. Tingkat aktivitas belajar Peserta Didik akan tercermin pada tinggi rendahnya skor mentah yang dicapai. Indikator Keberhasilannya adalah Hasil belajar Peserta Didik dikatakan meningkat apabila tercapai 
ketuntasan indifidu yaitu $\geq 65$ dan ketuntasan klasikalnya yaitu $\geq 85 \%$, Aktivitas Dosen ( Peneliti ) dikatakan meningkat apabila mencapai skor minimal berkategori baik dan Aktivitas belajar Peserta Didik dikatakan meningkat apabila mencapai skor minimal berkategori Aktif.

\section{HASIL DAN PEMBAHASAN}

Pelaksanaan kegiatan penelitian ini dilaksanakan untuk mengetahui pemenuhan hasil belajar Mahasiswa kelas A Semester II tahun Akademik 2017/2018 di Program Studi Pendidikan Matematika STKIP Bima, serta kegiatan Dosen dan Mahasiswa dengan menerapkan metode questioning type open ended problems (Ekplorasi, Pengenalan, dan Aplikasi konsep) pada materi Perintah / Statement.

Penelitian ini dilaksanakan dengan 4 kali pertemuan tiap siklusnya dari bulan Februari sampai dengan Bulan juni 2018.. Data-data tersebut kemudian dianalisis dengan menggunakan rumus yang telah ditetapkan sebelumnya.

Hasil penelitian siklus I Proses Perkuliahan pada siklus I berlangsung dalam 4 (Empat) kali pertemuan, dimana tiap-tiap pertemuan berlangsung selama 2 x 45 menit dan 1(satu) kali kegiatan evaluasi selama 2 x 45 menit. Pada siklus I pertemuan pertama yang dilaksanakan pada tanggal 13 Februari 2018 dengan materi yang disesuaikan dengan RPS, yaitu pada pokok bahasan Perintah / Statement, pengertian Perintah / Statement serta fungsinya dalam dalam menghasilkan sebuah program. Sedangkan pada pertemuan kedua dilaksanakan pada tanggal 20 Februari 2018 dengan materi yang diberikan adalah pengertian Perintah / Statement. Dan pada pertemuan ketiga pada tanggal 27 Februari 2018 dengan materi yang diberikan adalah penerapan sebuah fungsi dalam membentuk sebuah program dan pada tanggal 06 maret 2018 digunakan untuk evaluasi.

Kegiatan pada siklus I terdiri dari Tahap Perencanaan, Menyiapkan skenario Perkuliahan (RPS) sesuai dengan metode Perkuliahan questioning type open ended problems, Menyiapkan pedoman observasi untuk mencatat kegiatan Perkuliahan Mahasiswa dan kegiatan Dosen selama Perkuliahan berlangsung, Membuat LKS, soal tes evaluasi Perkuliahan. 
Tabel 2 : Data hasil observasi aktivitas Dosen siklus I

\begin{tabular}{|c|c|c|c|c|}
\hline \multirow{2}{*}{ No } & \multirow{2}{*}{ Tahap yang diobservasi } & \multicolumn{3}{|c|}{ Skor indikator } \\
\cline { 3 - 5 } & & Pert. I & Pert. II & Pert. II \\
\hline 1 & Tahap Pemahaman & 4 & 4 & 4 \\
\hline 2 & Tahap Aplikasi & 4 & 5 & 5 \\
\hline 3 & Tahap Penerapan & 5 & 5 & 5 \\
\hline & Jumlah skor indikator & 12 & 14 & 14 \\
\hline
\end{tabular}

Dari data tersebut dapat ditentukan pertemuan I, II dan III memiliki kenaikan kriteria ketuntasan cukup baik. Sehigga dapat disimpulan bahwa kriteria ketutasan Dosen pada siklus I dalam kriteria ketuntasan cukup baik dengan nilai rata - rata 4,4.

Tabel 3 : Data hasil observasi aktivitas Mahasiswa siklus I

\begin{tabular}{|c|c|c|c|c|}
\hline \multirow{2}{*}{ No } & \multirow{2}{*}{ Tahap yang diobservasi } & \multicolumn{3}{|c|}{ Skor indikator } \\
\cline { 3 - 5 } & & Pert. I & Pert. II & Pert. III \\
\hline 1 & Tahap Pemahaman & 4 & 4 & 5 \\
\hline 2 & Tahap Aplikasi & 4 & 5 & 5 \\
\hline 3 & Tahap Penerapan & 3 & 3 & 4 \\
\hline & Jumlah skor indikator & 11 & 12 & 14 \\
\hline
\end{tabular}

Dari Data tersebut dapat ditentukan pertemuan I, pertemuan II dan pertemuan III memiliki kriteria ketuntasan cukup baik dengan nilai rata - rata 3,7, 4,0 dan 4,7. Sehigga dapat disimpulan bahwa kriteria ketutasan Mahasiswa pada siklus I dalam kriteria ketuntasan cukup baik dengan nilai rata - rata 4,1 .

Kegiatan evaluasi dilakukan pada setiap akhir siklus yang merupakan bagian dari langkah dalam memberikan tes dalam bentuk essay yang dikerjakan secara individu., data tersebut diolah dan dianalisis sebagai berikut:

Tabel 4 : Hasil evaluasi belajar Mahasiswa suklus I

\begin{tabular}{|l|l|}
\hline Jumlah Mahasiswa & 26 \\
\hline Nilai tertinggi & $\mathbf{8 6}$ \\
\hline
\end{tabular}




\begin{tabular}{|l|c|}
\hline Nilai terendah & 28 \\
\hline Jumlah Skor Akhir & 1661 \\
\hline Nilai rata-rata & $\mathbf{6 3 , 8 8}$ \\
\hline Banyak Mahasiswa yang tuntas & 17 \\
\hline Banyak Mahasiswa yang tidak tuntas & 9 \\
\hline
\end{tabular}

Dari tabel diatas dapat disimpulkan bahwa rata - rata hasil belajar Mahasiswa pada siklus I adalah 63,88 dengan presentase ketuntasan 65,38 \%, ketuntasan belajar tersebut sudah memenuhi indikator keberhasilan. Ketuntasan belajar tersebut sudah memenuhi indikator dalam penelitian ini, Namun peneliti tetap melanjutkan penelitian pada siklus dua guna mencari tahu peningkatan dalam tiap siklus dan juga memaksimalkan hasil penelitian.

Tahap refleksi merupakan kegiatan yang dilakukan untuk melihat kembali kekurangan - kekurangan dimana Peneliti masih kurang memaparkan tujuan Perkuliahan. Dosen hendaknya memaksimalkan tujuan Perkuliahan, Masih ada Mahasiswa yang kurang percaya diri untuk tampil didepan kelas, baik dalam penyampaian hasil diskusi maupun dalam mengerjakan soal dipapan tulis.

Dosen hendaknya meningkatkan motivasi kepada Mahasiswa agar Mahasiswa lebih percaya diri, Masih terdapat Mahasiswa yang belum beradaptasi tentang penerapan model Perkuliahan saat proses presentasi antar kelompok, Dosen hendaknya sedikit menjelaskan tentang penerapan model Perkuliahan yang dipakai, Sebagian Mahasiswa masih sangat sulit memahami materi, Mencari cara agar mahasiswa untuk dapat memahami materi yang di ajarkan.

Tabel 5 : Data hasil observasi aktivitas Dosen siklus II

\begin{tabular}{|l|l|c|c|c|}
\hline \multirow{2}{*}{ No } & \multirow{2}{*}{ Tahap yang diobservasi } & \multicolumn{3}{|c|}{ Skor indikator } \\
\cline { 3 - 5 } & & Pert. I & Pert. II & Pert. II \\
\hline 1 & Tahap Pemahaman & 4 & 4 & 4 \\
\hline 2 & Tahap Aplikasi & 4 & 4 & 5 \\
\hline 3 & Tahap Penerapan & 5 & 5 & 5 \\
\hline & Jumlah skor indikator & 13 & 13 & 14 \\
\hline
\end{tabular}


Dari data tersebut dapat ditetapkan bahwa pertemuan I, II dan pertemuan III memiliki kriteria ketuntasan cukup baik dengan nilai rata - rata 4,4. Sehigga kesimpulannya bahwa kriteria ketutasan Dosen siklus II dalam kriteria ketuntasan cukup baik dengan nilai rata - rata 4,4 .

Tabel 6 : Data hasil observasi aktivitas Mahasiswa siklus II

\begin{tabular}{|c|c|c|c|c|}
\hline \multirow{2}{*}{ No } & \multirow{2}{*}{ Tahap yang diobservasi } & \multicolumn{3}{|c|}{ Skor indikator } \\
\cline { 3 - 5 } & & Pert. I & Pert. II & Pert. III \\
\hline 1 & Tahap Pemahaman & 4 & 4 & 4 \\
\hline 2 & Tahap Aplikasi & 4 & 5 & 5 \\
\hline 3 & Tahap Penerapan & 5 & 5 & 5 \\
\hline & Jumlah skor indikator & 13 & 14 & 14 \\
\hline
\end{tabular}

Dari Data tertera pertemuan I, II dan pertemuan III memiliki kriteria ketuntasan cukup baik dengan nilai rata - rata 4,3, 4,6 dan 4,6. Sehigga dapat disimpulan kriteria ketutasan Dosen pada siklus II dalam kriteria ketuntasan cukup baik dengan nilai rata - rata 4,5 .

Kegiatan evaluasi dilakukan pada setiap akhir siklus dalam memberikan tes dalam bentuk essay yang dikerjakan secara individu.

Tabel 7 : Hasil evaluasi belajar Mahasiswa siklus II.

\begin{tabular}{|l|c|}
\hline Jumlah Mahasiswa & 26 \\
\hline Nilai tertinggi & $\mathbf{9 2}$ \\
\hline Nilai terendah & 48 \\
\hline Jumlah Skor Akhir & 1867 \\
\hline Nilai rata-rata & $\mathbf{7 1 , 8 1}$ \\
\hline Banyak Mahasiswa yang tuntas & 23 \\
\hline Banyak Mahasiswa yang tidak tuntas & 3 \\
\hline
\end{tabular}

Dari diatas dapat disimpulkan bahwa rata - rata hasil belajar Mahasiswa pada siklus II adalah 71,81 dengan presentase ketuntasan 87,5 \%, ketuntasan belajar tersebut jauh memenuhi indikator keberhasilan. Dengan demikian penelitian ini dihentikan pada siklus II.

Tahap refleksi, Masih ada sebagian Mahasiswa yang kurang paham dalam mengimplementasikan sebuah permasalahan, Perlunya latihan yang rutin dengan contoh soal yang berbeda dengan memanfaatkan materi so'al yang berbeda pula, Dosen hendaknya mengarahkan pada mahasiswa yang kurang mengerti tersebut agar dapat berkonsultasi pada teman-temannya yang sudah mengerti, Dosen memberikan soal latihan atau tugas yang dapat 
melatih kecerdasan penalaran dalam mengimplementasikan permasalahan dengan materi yang di ajarkan.

\section{KESIMPULAN}

Dari hasil penelitian dan pembahasan dapat ditarik kesimpulan bahwa pembelajaran dengan menerapkan Model Pembelajaran Questioning Type Open Ended Problems dapat meningkatkan Hasil belajar matemátika pada materi Pemrograman Komputer Mahasiswa Semester II-A STKIP Bima Jika, Model Pembelajaran Questioning Type Open Ended

Problems diterapkan secara optimal sesuai dengan karakteristik pada pembelajaran matematika. Hal ini dapat dilihat dari perolehan nilai rata-rata data data ditipa siklus dimana pada siklus I nilai rata-rata Mahasiswa 66,25 dengan ketuntasan 87,5\% kemudian meningkat pada siklus II dengan nilai rata - rata 74,5 dengan ketuntasan 91,6\%.

\section{UCAPAN TERIMAKASIH}

Puji syukur penulis panjatkan kehadirat Allah SWT, karena berkat rahmat dan hidayahNya penulis dapat menyelesaikan Atikel penelitian yang berjudul "Upaya meningkatkan Hasil Belajar Mahasiswa melalui Model Pembelajaran Questioning Type Open Ended Problems. Artikel ini dilaksanakan dalam rangka pemenuhan Tridarma Perguruan Tinggi, dalam hal ini tentang penelitian Dosen. Melalui kesempatan ini peneliti tidak lupa menyampaikan rasa terima kasih yang sebesar-besarnya kepada semua pihak yang telah banyak membantu selama penyusunan proposal ini terutama kepada yang terhormat:

1. Bapak Drs. Zainudin Muksin,MM, selaku Kepala LP2M STKIP Bima.

2. Bapak Edi Mulyadin,S.Pd.,M.Pd,selaku Ketua Prodi Matematika.

3. Semua pihak yang telah membantu penulisan proposal ini.

Semoga Tuhan memberikan imbalan atas segala bantuan, Arahan, masukkan atau petunjuk yang telah diberikan dan semoga artikel ini dapat bermanfaat bagi pengembangan ilmu.

\section{REFERENSI}

Drs. Darhim \& Drs. Didi Suryadi,Pengenalan Komputer dan Bhs. BASIC. Kelompok Penulis Profesional Pengembangan Pendidikan Tinggi dan Menengah Bandung - Indonesia.

Tutang ED.Rev ( 2002 ), Pengenalan Komputer., Jakarta Data Com

Jogiyanto Hartono, MBA, Ph.d. (Dosen Tetap UGM ) (1999), Pengenalan Komputer., Andi Yogyakarta. 
Arikunto S. (2010). Prosedur Penelitian. Jakarta: Rineka Cipta

Khoo A. (2008). Buku Pintar Anak Jenius. Jakarta: PT Mitra Media

Masykur Ag M. dan Fathani A. H. (2007). Mathematical Intelligence. Cara Cerdas Melatih Otak Dan Menanggulangi Kesulitan Belajar: Ar-Ruzz Media.

Soepiadhy S. (2011). Rahasia Anak Jenius. Surabaya: PT. Java Pustaka

Sugilar dan Juandi D. (2011). Metode Penelitian Pendidikan Matematika. Jakarta: Universitas Terbuka.

Sutawidjaja A. dan Afgani D. J. (2011). Pembelajaran Matematika. Jakarta: Universitas Terbuka.

Sri Lestari dan Pradnyo Wijayanti (2013), "Proses Berpikir Kritis Siswa dalam Memecahkan Masalah Matematika Open Ended Ditinjau dari Kemampuan Matematika Siswa dan Perbedaan Jenis Kelamin pada Materi Kubus dan Balok," Jurnal Matematika, (Surabaya: UNESA FMIPA, 